\title{
Onafhankelijkheid vs. Accountability: de casus van de nieuwe EU financiële toezichthouders ${ }^{*}$
}

\author{
M. Scholten
}

\section{Introductie}

$\mathrm{Na}$ ingrijpende gebeurtenissen, zoals de recente financiële crisis, komt de discussie over de meest effectieve vorm van regulering en handhaving vaak op. Dit leidt meestal, onder andere, tot het invoeren van nieuwe regelgeving of het aanpassen (versterken) van bestaande regels en handhavingsmechanismen om soortgelijke evenementen in te toekomst te voorkomen. Tegelijkertijd wil men effectief zijn in de beleidscyclus.

De onafhankelijke bestuursorganen worden vaak gecreëerd naar aanleiding van een crisis $^{1}$ en gezien als een manier om effectiviteit in de beleidscyclus te verhogen; 'because they are one step removed from election returns', ${ }^{2}$ onafhankelijke agentschappen worden geacht 'to develop and employ expertise in order to produce, or help principals produce appropriate public policy'. ${ }^{3}$ Echter, de mogelijke oplossing voor een probleem brengt een andere uitdaging mee: 'independent, hence unaccountable'. ${ }^{4}$ Een ongemakkelijke verhouding tussen onafhankelijkheid en accountability kan bestaan door het feit dat politieke verantwoordelijkheid normaliter via de minister loopt; iets wat bemoeilijkt wordt door de onafhankelijke status van agentschappen. ${ }^{5}$

Hoewel het debat over hoe de wetgever accountability van onafhankelijke agentschappen kan verzekeren niets nieuws is, bestaan er verschillen wat betreft hoe de wetgevers met dit dilemma omgaan. De situatie in de EU waarbij een aantal onafhankelijke maar accountable financiële toezichthouders recent zijn ingesteld,

* De auteur is zeer dankbaar voor het inhoudelijke en taalkundige commentaar op de oorspronkelijke versie van dit artikel aan de redactie van RegelMaat, prof. mr. Rob van Gestel, dr. Pablo Iglesias-Rodríguez, dr. Daniel Scholten en Bjorn Kleizen.

1 Dit geldt bijvoorbeeld voor de Europese Autoriteit voor Voedselveiligheid (EFSA in de Engelse vertaling), die naar aanleiding van een aantal voedselcrises in de jaren negentig van de vorige eeuw is opgericht; voor het Europees Agentschap voor Maritieme Veiligheid (EMSA in de Engelse vertaling), die ontstaat als gevolg van zeevaartrampen, zoals het ongeluk met olietanker Erika; en de nieuwe EU financiële toezichthouders, die in dit artikel worden besproken.

2 G. Majone, Regulating Europe, Londen: Routledge, 1996, p. 41.

3 M. Thatcher \& A. Stone Sweet, Theory and Practice of Delegation to Non-Majoritarian Institutions, in: M. Thatcher \& A. Stone Sweet (red.), The Politics of Delegation, London: Frank Cass 2003, p. 4.

4 M. Scholten, Independent, hence unaccountable? The need for a broader debate on accountability of the executive, Review of European Administrative Law 2011, vol. 4, no. 1.

5 L. Verhey, H. Broeksteeg \& I. van den Driessche, Political Accountability in Europe: Which Way Forward?: A Traditional Concept of Parliamentary Democracy in an EU Context, Groningen: Europa Law Publishing 2008. 
lijkt te verschillen van de ervaringen op het nationale niveau. Hoewel Europese Toezichthouders (ESA's in de Engelse vertaling), vergelijkbaar met het nationale niveau, ontworpen zijn om onafhankelijk te zijn ten opzichte van de Commissie, heeft de Uniewetgever directe politieke controle via de vertegenwoordigde lichamen (de Raad en het Europees Parlement (verder EP)) gecreëerd, twee nietunitaire instituties wat hun samenstelling betreft. Dit artikel analyseert de onafhankelijkheid en accountability van de nieuwe EU financiële agentschappen en trekt een aantal lessen voor nationale wetgevers, die zich met het 'onafhankelijkheid vs. accountability'-dilemma geconfronteerd zien.

Het artikel bestaat verder uit vijf delen. Het richt zich eerst op het 'onafhankelijkheid vs. accountability'-dilemma waar drie elementen van onafhankelijkheid worden onderscheiden, welke de kern zullen vormen voor de vergelijkende analyse (deel 2). Na een kort overzicht van de vorming van de nieuwe EU financiële agentschappen en hun taken (deel 3) vergelijkt het artikel de onafhankelijkheid en accountability arrangementen van de nieuwe toezichthouders met de voorgangers van deze agentschappen, de zogenoemde Lamfalussy-comités aan de hand van de drie elementen van onafhankelijkheid. Terwijl de vergelijking laat zien dat de de jure onafhankelijkheid en accountability van de ESA's is versterkt (deel 4), in elk geval in vergelijking met hun voorgangers, geeft dit artikel ook een aantal opmerkingen over de de facto onafhankelijkheid en accountability van EU-agentschappen (deel 5). De lessen voor de nationale wetgever sluiten dit artikel af (deel 6).

\section{De spanning tussen onafhankelijkheid en accountability}

Het verschil tussen onafhankelijke en andere regelgevende agentschappen zit niet noodzakelijkerwijs in de hoeveelheid en de aard van de functies die deze organisaties bezitten. De functies die de verschillende EU-agentschappen uitvoeren (informatieverzameling, advisering, samenwerking, besluitvorming, toezicht en handhaving) kunnen allemaal ook worden uitgevoerd door de Europese Commissie en/ of nationale autoriteiten, instituties die niet noodzakelijkerwijs onafhankelijk zijn. ${ }^{6} \mathrm{Zo}$ is het in de Verenigde Staten voor alle agentschappen, onafhankelijk of niet, mogelijk om functies met betrekking tot regelgeving (rulemaking), geschilbeslechting (adjudication) en andere functies, zoals handhaving (enforcement), die bij wet voorgeschreven zijn, te vervullen. Wat onafhankelijke agentschappen onderscheidt van andere agentschappen is daarom niet zo zeer de bevoegdheden die ze bezitten, maar hun onafhankelijke of autonome status. Regelgevers die een zekere mate van autonomie van mogelijk frequent veranderende politieke principalen (en wellicht van stakeholders) genieten, worden geacht in een betere positie te verkeren om effectief langeretermijndoelstellingen te realiseren en om de langeretermijngeloofwaardigheid van politieke toezegging te verbeteren dan, bij- 
voorbeeld, ministeries. Wat houdt onafhankelijkheid in? En hoe verhoudt het zich tot accountability?

Onafhankelijkheid is een middel om functionele discretie die is toegekend aan agentschappen te beschermen. ${ }^{7}$ Functionele discretie is de mogelijkheid om inhoudelijke en/of procedurele keuzes te maken, die bij de delegatie van taken aan verschillende organisaties, onafhankelijk of niet, wordt toegekend. Dit gebeurt omdat de wetgever vooraf niet alles precies kan specificeren, vooral wanneer het gaat om de delegatie van, vaak zeer technische, regelgevende taken. Regelgevende agentschappen kunnen daarom bijvoorbeeld zelf kiezen of ze door middel van een gemeenschappelijke regel of door middel van individuele besluiten (het procedurele type functionele discretie) reguleren, of hoe ze bijvoorbeeld het niveau van bepaalde emissies dat benodigd is om de volksgezondheid te waarborgen bepalen (het inhoudelijke type functionele discretie). Bijvoorbeeld: een van de taken van de US Environmental Protection Agency (het Milieubeschermingsagentschap) is het opstellen van emissiestandaarden 'the attainment and maintenance of which (...) are requisite to protect the public health' ${ }^{8}$ Het agentschap geniet dus aanzienlijke discretie om te bepalen welk niveau van bescherming nodig is om de volksgezondheid te waarborgen en welke emissieniveaus niet voldoen. Functionele discretie kan en dient samen te gaan met accountability: wanneer een uitvoerende institutie een regel heeft uitgegeven aan de hand van zijn relevante statutaire vereisten, dient deze institutie voor volksvertegenwoordigers en andere accountabilityfora verantwoording af te leggen over de inhoud en het hoe en waarom van zijn acties.

Om de mogelijkheid tot het vrijelijk maken van inhoudelijke en/of procedurele keuzes voor sommige agentschappen te beschermen, kan de wetgever ervoor kiezen een agentschap op afstand te brengen van het hoofd-uitvoerende orgaan (een ministerie, een presidentiële dienst of de EU-Commissie) om zo de invloed van laatstgenoemde over de keuzes van het agentschap te reduceren. Door een agentschap vorm te geven als aparte juridische entiteit (geen onderdeel van bijvoorbeeld een ministerie) en door rapportageverplichtingen richting het uitvoerende orgaan te verwijderen kan de institutionele en persoonlijke onafhankelijkheid bevorderd worden. De persoonlijke onafhankelijkheid van topambtenaren in agentschappen kan ook worden bevorderd door meer instituties (wellicht met conflicterende belangen) te betrekken bij de benoeming van het hoofd van agentschappen. Als een kandidaat acceptabel is voor instituties met verschillende belangen, zal deze minder snel het belang van één bepaalde partij behartigen na zijn benoeming. Daarnaast kan het beperken van de mogelijkheid voor politieke instituties om leidinggevenden te ontslaan de persoonlijke onafhankelijkheid

7 M. Scholten, Accountability vs. Independence: Proving the Negative Correlation, Maastricht Journal of European and Comparative Law 2014, Issue 1.

8 Van de taken van de oprichtingsakte van het VS Milieubeschermingsagentschap (42 USC $\S 7409)$. Voor een discussie over de geschiktheid van een dergelijk brede delegatie van bevoegdheden naar agentschappen in zulke ambigue termen: Whitman v. American Trucking Associations (531 U.S. 457 (2001)). 
waarborgen. De zogenoemde verwijdering 'om redenen' toepasbaar op leden van onafhankelijke agentschappen in de VS impliceert dat de Amerikaanse president niet in staat is zonder afdoende grond zulke leden te ontslaan. ${ }^{9}$ Ten slotte, omdat geld de activiteiten van agentschappen bepaalt, hangt functionele discretie ook in hoge mate af van financiële onafhankelijkheid. Dit impliceert het losmaken van de budgetten van agentschappen van dat van het (hoofd-)uitvoerende orgaan, de mogelijkheid om middelen van het ene programma naar het andere over te brengen en de zelfvoorzienendheid van agentschappen.

Hoewel de drie elementen van onafhankelijkheid de functionele discretie kunnen waarborgen door de 'command-control' relatie met de primaire uitvoerende macht te verbreken, beïnvloedt een dergelijke stap een aantal verantwoordingsrelaties en -mechanismen. Het institutioneel onafhankelijk maken en verwijderen van de 'command-control' link tussen die leiding van het onafhankelijke agentschap en het uitvoerende orgaan, waaronder het agentschap officieel ressorteert, impliceert het ontbreken van de mogelijkheid om een minister, president of de EU-Commissie ter verantwoording te roepen voor de prestaties van het agentschap. Op deze manier kan gesproken worden van een vermindering van accountability kanalen. Immers, als een agentschap wel onder het gezag van het hoofd-uitvoerende orgaan staat, is het voor het politieke verantwoordingsforum mogelijk om dit uitvoerende orgaan (bijvoorbeeld de minister) ter verantwoording te roepen voor de prestatie van het agentschap. Vanuit het financiële perspectief betekent het zelfvoorzienend maken van een agentschap een vermindering van de instrumenten die het politieke gezag tegen een onafhankelijk agentschap kan inzetten. Zelfvoorzienende agentschappen, zoals de Federal Reserve in de VS of het Communautair Bureau voor Plantenrassen in de EU, leggen geen financiële verantwoording af naar vertegenwoordigende lichamen (respectievelijk het Amerikaanse Congres, de Raad en het EP) in de loop van de jaarlijkse budgettaire procedures (en kwijtingsprocedure wat betreft de EU). Om die redenen beschikken politieke verantwoordingsfora over minder accountability instrumenten om zelfvoorzienende agentschappen ter verantwoording te roepen.

De besproken drie elementen van onafhankelijkheid maken niet automatisch dat een agentschap geen verantwoording hoeft af te leggen. Hoewel agentschappen niet 'accountable' zijn tegen het hoofd-uitvoerende orgaan, kunnen ze wel direct verantwoording afleggen naar vertegenwoordigende lichamen en/of direct naar het volk. Dit lijkt het geval te zijn wat betreft de drie recent gecreëerde Europese financieeltoezichthouders. 


\section{EU financiële toezichthouders: oorsprong en taken}

De hervorming van de Europese regelgeving en het toezicht op de financiële markten heeft zowel in functioneel als in institutioneel opzicht plaatsgevonden. Het functionele perspectief betreft de reallocatie van de taken van nationale en EU-toezichthouders, waarbij de laatstgenoemde meer en sterkere regulerende en toezichthoudende bevoegdheden hebben verkregen, variërend van adviserende tot besluitvormings- en exclusieve toezichthoudende bevoegdheden, in vergelijking met de taken van hun voorgangers, de zogenoemde Lamfalussy-comités. Om deze nieuwe functies uit te oefenen zijn voormalige adviescomités van de EUCommissie getransformeerd in onafhankelijke agentschappen, te weten de EBA, EIOPA en ESMA.

\section{De oorsprong van de nieuwe EU financiële toezichthouders}

Het Lamfalussy-proces kwam voort uit het Eindrapport van de Commissie van Wijzen over de Regulering van de Europese Effectenmarkten uit 2001. Een van de hoofdconclusies van dit rapport was dat de bestaande regulering te langzaam, rigide en onduidelijk was. Om die reden zou een hogere gradatie van convergentie tussen lidstaten en een meer nadrukkelijke aanwezigheid van de Europese Gemeenschap in de handhaving noodzakelijk zijn. ${ }^{10}$

Het 'Lamfalussy-proces' was gebaseerd op een regelgevende aanpak bestaande uit vier niveaus. De eerste twee niveaus, te weten het aannemen van noodzakelijke wetgeving (niveau 1) en het opzetten van twee nieuwe comitologiecomités om de Commissie te assisteren bij het implementeren van de details van die wetgeving (niveau 2), waren reacties van reguleringszijde. De andere twee niveaus, te weten het verbeteren van de samenwerking tussen de relevante nationale autoriteiten (niveau 3) en het versterken van de rol van de Commissie in het implementatieproces van gemeenschappelijke regels (niveau 4), waren gericht op het verzekeren van een consistente implementatie en een verbeterde handhaving van EU-wet- en regelgeving.

Wat het laatste betreft: om de consistente transpositie, implementatie en handhaving van wet- en regelgeving uit niveaus 1 en 2 te garanderen heeft de Europese Commissie op niveau 3 adviescomités in het leven geroepen: het Comité van Europese toezichthouders op banken (CEBS in de Engelse vertaling), het Comité van Europese toezichthouders op verzekeringen en bedrijfspensioenen (CEIOPS in de Engelse vertaling) en het Comité van Europese Effectenregelgevers (CESR in de Engelse vertaling). Afgevaardigden van nationale regelgevende autoriteiten van iedere lidstaat namen zitting in deze comités, die enerzijds een effectievere

10 T. Tridimas, EU Financial Regulation: Federalization, Crisis Management, and Law Reform, in: P. Craig \& G. de Burca (red.), The Evolution of EU Law, second edition, Oxford: Oxford University Press 2011, p. 783. 
samenwerking tussen nationale regelgevende autoriteiten moesten bewerkstelligen en anderzijds aan de convergentie van toezichtspraktijken moesten bijdragen. ${ }^{11}$

Niveau 3-comités hadden geen directe toezichthoudende bevoegdheden over individuele marktdeelnemers. In plaats daarvan speelden zij een meer indirecte rol door consistente, samenwerkingsgezinde handelswijzen en open relaties tussen de betrokken nationale toezichthouders te bevorderen en door sociale druk door te bewerkstelligen waar nationale autoriteiten verschillen vertoonden. ${ }^{12}$ De netwerken van nationale afgevaardigden waren de plaats waar uitwisseling van best practices plaatsvond en waar richtlijnen en standaarden voor nationale autoriteiten werden opgesteld door middel van bijvoorbeeld peer reviews van bestuursrechtelijke regelgeving en regelgevende praktijken in individuele landen. Dergelijke standaarden en richtlijnen waren noch juridisch bindend, noch handhaafbaar en hadden alleen indirect effect via de wijze waarop nationale regelgeving werd toegepast.

Hoewel het Lamfalussy-systeem de samenwerking tussen EU-lidstaten heeft verbeterd, vormde de financiële crisis van 2008 een stevige uitdaging voor de funderingen van het systeem. De crisis onthulde de noodzaak om het systeem te hervormen via verdergaande integratie. Het De Larosière-rapport, uitgegeven door een groep experts op mandaat van de Commissie en onder voorzitterschap van Jacques de Larosière, liet de gebreken van de Lamfalussy-architectuur zien, zoals een gebrek aan convergentie tussen nationale toezichts- en handhavingswetgeving en -praktijken.

Het gebrek aan bindende regelgevende bevoegdheden van 'niveau 3-comités' (CESR, CEBS en CEIOPS) werd in dit opzicht gezien als een dringend probleem. Sterkere bevoegdheden werden noodzakelijk geacht om inconsistenties en handhavingstekortkomingen op het nationale niveau aan te pakken. Dit leidde vervolgens tot de transformatie van de 'niveau 3-comités' zonder bindende bevoegdheden tot onafhankelijke EU-agentschappen met besluitvormings- en toezichtsbevoegdheden.

\section{EBA, EIOPA en ESMA: taken en bevoegdheden}

Het doel van de nieuwe EU financiële agentschappen (EBA, EIOPA en ESMA) is vastgelegd in de oprichtingsaktes van deze organisaties (Verordeningen 2010/1093/EU, 2010/1094/EU en 2010/1095/EU). Dit is 'de collectieve belangen te beschermen door bij te dragen tot de stabiliteit en doeltreffendheid van het financiële stelsel op de korte, middellange en lange termijn, in het belang van de economie, de burgers en het bedrijfsleven van de Unie' (art. 1 lid 5 van de Verordening strekkende tot de oprichting van de EBA). De taken van de autoriteiten

11 A. Ottow, Europeanization of the Supervision of Competitive Markets, 18 European Public La $w$ 1 (2012), 191, p. 206.

12 E. Ferran, Understanding the New Institutional Architecture of EU Financial Marker Supervision, in: E. Wymeersch, K.J. Hopt \& G. Ferrarini, Finacial Regulation and Supervision: A PostCrisis Analysis, Oxford: Oxford University Press 2012, p. 117. 
zijn onder andere het leveren van bijdragen aan de invoering van kwalitatief hoogstaande gemeenschappelijke regulerings- en toezichtnormen en -praktijken en tot de consistente toepassing van de juridisch bindende handelingen van de Unie; artikel 8 lid 1 geeft een uitgebreide lijst van alle taken. Om deze taken uit te oefenen beschikken de Autoriteiten over de bevoegdheden om, bijvoorbeeld, voorstellen voor technische reguleringsnormen en uitvoeringsnormen te ontwikkelen; richtsnoeren en aanbevelingen te geven; in specifieke gevallen aanbevelingen en adviezen te doen (art. 8 lid 2).

Artikel 16 lid 1 van de ESA's oprichtingsaktes bepaalt dat de Autoriteiten richtlijnen en aanbevelingen aan de bevoegde autoriteiten of de financiëlemarktdeelnemers kunnen verstrekken. Hoewel deze niet juridisch bindend zijn voor de geadresseerden en er geen mogelijkheid tot handhaving bestaat, ${ }^{13}$ lijken de maatregelen ook niet geheel vrijwillig te zijn. ${ }^{14}$ Ingevolge het 'comply or explain' mechanisme uit artikel 16 lid 3 van de oprichtende verordeningen van agentschappen dienen de bevoegde autoriteiten en financiëlemarktdeelnemers zich tot het uiterste in te spannen om aan de richtlijnen en aanbevelingen te voldoen. De regel is dat alle bevoegde autoriteiten die hun geadresseerden zijn van een richtlijn of aanbeveling binnen twee maanden na publicatie moeten inlichten of zij aan de richtlijn of aanbeveling voldoen of willen voldoen. ${ }^{15}$

De drie agentschappen zijn op nagenoeg identieke oprichtingsaktes gebaseerd. Bovendien hebben alle drie de agentschappen bovenop de adviserende rol van hun voorgangers een aantal regelgevende en toezichthoudende bevoegdheden gekregen, waaronder de bevoegdheid instructies te geven aan de relevante financiële instituties, waarbij nationale toezichthouders gepasseerd worden indien laatstgenoemde geen gehoor geven aan de formele mening van de Commissie of de besluiten van de ESA's. ${ }^{16}$ De stadia van het handhavingsproces onder artikel 17 van de verordeningen behelzen onder meer de volgende elementen:

1 Onderzoek door de ESA's ->

2 Aanbeveling van de ESA's aan de nationale autoriteiten waarin wordt uiteengezet hoe aan het Unierecht te voldoen ->

3 Formeel advies aan de nationale autoriteit door de Commissie ->

4 ESA's besluit dat tot een specifieke financiëlemarktdeelnemer gericht is en dat conform het formele advies van de Commissie is.

13 P. Schammo, The European Securities and Markets Authority: lifting the veil on the allocation of powers, Common Market Law Review 2011, vol. 48, no. 6, p. 1881.

14 E. Wymeersch, The European Financial Supervisory Authorities or ESAs, in: E. Wymeersch, K.J. Hopt \& G. Ferrarini, Finacial Regulation and Supervision: A Post-Crisis Analysis, Oxford: Oxford University Press 2012, p. 276.

15 M. van Rijsbergen, On the enforceability of EU soft law measures at the national level. The case of the European Securities and Markets Authority, 2014 (nog te verschijnen).

16 In zaak C-270/12 hield het Hof van Justitie van de EU de mogelijkheid voor de EU-agentschappen in stand om algemeen verbindende regels uit te vaardigen. 
De bevoegdheden van de ESMA onder artikel 18 zijn als volgt:

Nadat de Raad heeft bepaald dat er sprake is van een noodsituatie in de zin van artikel 18 lid 1 zijn de ESA's bevoegd om besluiten te nemen strekkende tot specifieke handelingen door de nationale toezichthouders. Indien de nationale autoriteiten hieraan geen gehoor geven, is het in sommige gevallen voor de ESA's mogelijk besluiten direct aan financiëlemarktdeelnemers te richten.

Hoewel het originele idee was om bevoegdheden aan de nieuwe toezichthouders te geven strekkende tot het aannemen van bindende technische standaarden, is dit niet opgenomen in de uiteindelijke tekst. Deze bevoegdheden zijn nu voorbehouden aan de Commissie, die een 'single rulebook' zal aannemen op initiatief van de ESA's. ${ }^{17}$ Echter, zelfs zonder de regelgevende macht om bindende technische standaarden aan te nemen zijn de bevoegdheden van de ESA's behoorlijk sterk. De overdracht van dergelijke bevoegdheden aan de ESA's wijst op een belangrijke verschuiving van het primaat van het toezicht naar het EU-niveau. ${ }^{18}$

Verordening 2011/513/EU heeft ESMA exclusief verantwoordelijk gemaakt voor de registratie en het toezicht op ratingbureaus, waarbij ESMA de mogelijkheid heeft om sancties op te leggen. ${ }^{19}$ Dit impliceert dat, in elk geval wat betreft dit veld, bijna alle toezichtsbevoegdheden van het nationale niveau naar het Europese niveau worden overgedragen. ESMA's toezichtsbevoegdheden zijn uitgebreid. ESMA bezit onder andere bevoegdheden tot het onderzoeken en kopiëren van relevante documenten en materialen, het opvragen van mondelinge verklaringen, het oproepen en horen van personen, het opeisen van telefonie- en dataverkeergegevens en het interviewen van personen (art. 23 (b)). Dergelijke bevoegdheden zijn zelfs niet beschikbaar voor het EP in zijn onderzoekende rol. ESMA's arsenaal aan sancties betreft onder meer het intrekken van registraties, het opleggen van tijdelijke verboden tot het uitgeven van 'ratings', het opschorten van het gebruik van ratings voor regulerende doeleinden en het bekendmaken van besluiten (art. 24). Wat betreft handhavingsmaatregelen bezit ESMA slechts de mogelijkheid over te gaan tot een geldboete, waarbij de minimale en maximale bedragen vastgelegd zijn in artikel 36. Deze punitieve handhavingsmethode lijkt in de praktijk te zijn omzeild door het gebruik van risicogebaseerd toezicht en een ruime mate van discretie. Het is daarom waarschijnlijk dat ESMA alleen in uitzonderlijke omstandigheden over zal gaan tot het opleggen van een boete. ${ }^{20}$

17 A. Ottow, The New European Supervisory Architecture of the Financial Markets, in: M. Everson, C. Monda \& E. Vos (red.), European Agencies in Between Institutions and Member States, Kluwer Law International, te verschijnen in 2014, p. 123.

18 A. Ottow, Het Europese toezicht op de financiële markten, RegelMaat 2011, 4, p. 202-212.

19 K. Yesilkagit \& A. Ottow, Convergence of Sanctioning Regimes: A Sufficient Condition for Effective Enforcement of Financial Regulation? (nog te verschijnen), p. 21.

20 Ibid, p. 26. 
Het is belangrijk om op te merken dat ESMA niet de relevante nationale autoriteiten vervangt, aangezien het werk van ESMA afhankelijk is van nauwe samenwerking met de nationale toezichthouders. Naar gelang de relevante samenwerkingsverdragen kan van nationale toezichthouders worden verlangd dat zij informatie aanleveren, ESMA assisteren en namens ESMA onderzoek doen en inspecties ter plaatse uitvoeren. ESMA mag ook bepaalde taken overdragen aan nationale autoriteiten, hoewel een dergelijke overdracht de autoriteit van ESMA niet mag aantasten. In zijn totaliteit is het nieuwe regime, door middel van de centralisatie van competenties op EU-niveau, gericht op het verzekeren van een strengere controle op zowel de naleving van relevante regelgeving als de afgifte van informatie.

\section{De jure onafhankelijkheid en accountability}

De centralisatie van regulerings- en handhavingsbevoegdheden op het gebied van de Europese financiële markten had een aantal implicaties voor de onafhankelijkheid en accountability van de recent opgezette EU financiële toezichthouders. Deze gevolgen zullen besproken worden aan de hand van de eerder geïdentificeerde institutionele, persoonlijke en financiële elementen van onafhankelijkheid. ${ }^{21}$

Vanuit een institutioneel perspectief is de onafhankelijkheid en accountability van de nieuwe EU financiële agentschappen in vergelijking met hun voorgangers verbeterd. Hoewel de CESR, CEBS en CEIOPS ingesteld werden door middel van een besluit van de Commissie en buiten Brussel gevestigd werden (respectievelijk in Parijs, Londen en Frankfurt), waren dit geen lichamen met rechtspersoonlijkheid maar onafhankelijke adviesgroepen van de Commissie (art. 1 en 2 van het Besluit van de Commissie (2004/5/EG) tot instelling van CEBS). Ingevolge de oprichtingsaktes (verordeningen van de Raad en het EP) zijn de nieuwe EU financiële agentschappen onafhankelijke entiteiten met rechtspersoonlijkheid. Dit impliceert allereerst dat de agentschappen contractuele relaties aan kunnen gaan met derde partijen, wat bijvoorbeeld de mogelijkheid tot het zelfstandig huren van panden biedt. Ten tweede impliceert hun rechtspersoonlijkheid dat ze onderworpen zijn aan rechterlijke controle door het Hof van Justitie (art. 263 VWEU), wat tevens rechterlijke controle op de besluiten van de agentschappen bewerkstelligt. Bovendien, zodra een agentschap aanbevelingen of besluiten uitvaardigt, zullen deze onder andere op de internetsite van het agentschap gepubliceerd worden. Dit maakt het bijvoorbeeld mogelijk om na te gaan of, en zo ja in hoeverre, de Europese Commissie het advies van het agentschap heeft opgevolgd.

Het instellen van institutioneel onafhankelijke agentschappen is dus gepaard gegaan met de onderwerping van deze agentschappen aan meer accountability-

21 Zie ook Iglesias-Rodríguez voor een analyse van de onafhankelijkheid en accountability van de nieuwe financiële EU-agentschappen: P. Iglesias-Rodríguez, The Accountability of Financial Regulators: A European and International Perspective, Kluwer Law International 2014, hoofdstukken 6 en 7. 
verplichtingen richting de EU-vertegenwoordigende instituties dan hun voorgangers (zie Tabel 1). Waar de CEBS, CEIOBS en CESR hun jaarlijkse rapporten naar de Commissie stuurden, die ze op haar beurt vervolgens doorstuurde naar de Raad en het EP, moeten de nieuwe agentschappen hun rapporten direct naar de Raad en het EP sturen. Bovendien hadden de voorzitters van de voormalige comités de verplichting om periodiek verslag uit te brengen aan het EP en op verzoek ook aan de Raad. De oprichtingsaktes van de nieuwe agentschappen specificeren dat de voorzitters van de agentschappen schriftelijk aan het EP verslag moeten uitbrengen over de prestaties van deze agentschappen en dat het EP de voorzitter mag verzoeken om extra informatie aan te leveren. Bovendien introduceren de oprichtingsaktes verplichte hoorzittingen, waarbij de voorzitters van de agentschappen voor het EP en de Raad moeten verschijnen. Verder zijn de agentschappen onderworpen aan een evaluatiebepaling die impliceert dat in januari 2014, en vervolgens om de drie jaar, de Commissie het opereren van de agentschappen dient te evalueren en daarover een rapport dient te publiceren ten behoeve van het EP en de Raad.

De persoonlijke onafhankelijkheid en accountability van leden van de raad van toezichthouders en de voorzitter lijkt op de volgende manier verzekerd te zijn.

Allereerst is naast de Europese Raad, het EP nu betrokken bij de benoeming en verwijdering van topambtenaren voor de nieuwe agentschappen, specifiek de voorzitter en de directeur. De betrokkenheid van meer instituties die verschillende groeperingen en mogelijk conflicterende belangen vertegenwoordigen, kan als voordelig gezien worden voor de neutraliteit van de benoemde personen en de transparantie van het benoemingsproces. Ook wordt de verantwoordingsrelatie helderder. De Lamfalussy-comités werden beheerst door de lidstaten aangezien ze bestonden uit de vertegenwoordigers van de relevante nationale autoriteiten. De voorzitter van het comité werd uit het midden van de comitéleden gekozen door middel van consensus of een twee derde meerderheid van de stemgerechtigde leden. De nieuwe agentschappen bezitten een meer doordachte structuur. De raad van toezichthouders is het hoogste orgaan van de agentschappen en bestaat uit de voorzitters van de nationale autoriteiten bevoegd tot het houden van toezicht op kredietinstituties en een aantal niet-stemgerechtigde leden, zoals de voorzitter, één lid van de Commissie, één lid van de Europese Centrale Bank, één lid van het Europees Comité voor Systeemrisico's en één lid van de andere twee toezichthoudende autoriteiten (bijvoorbeeld EIOPA en ESMA in het geval van de EBA). Deze raad van toezichthouders neemt de belangrijkste besluiten van het agentschap. De voorzitter, die het agentschap vertegenwoordigt, wordt aangewezen door de raad van toezichthouders, hoewel tegen de benoeming bezwaar gemaakt kan worden door het EP. Hoewel de verordeningen niet specificeren in hoeverre de raad gebonden is aan een dergelijk bezwaar, is het indienen ervan in elk geval een belangrijk politiek signaal. Daarnaast kan de voorzitter verwijderd worden door het EP na een besluit van de raad van toezicht van de agentschap. De voorzitter kan ook door de Raad en het EP worden uitgenodigd om verslag uit te brengen over de prestaties van het agentschap. De directeuren van het agentschap zijn 
verantwoordelijk voor het dagelijks bestuur en het budget van het agentschap en worden benoemd na goedkeuring door het EP, een bevoegdheid waar het EP ten opzichte van agentschappen nog niet eerder over heeft kunnen beschikken.

Ten tweede stelt artikel 42 van de verordeningen op de EBA, EIOPA en ESMA expliciet dat 'bij de uitvoering van de bij deze verordening aan hen opgedragen taken handelen de voorzitter en de stemgerechtigde leden van de raad van toezichthouders onafhankelijk en objectief uitsluitend in het belang van de Unie in haar geheel en vragen noch aanvaarden zij instructies van instellingen of organen van de Unie, van de regering van een lidstaat of van een ander publiek of privaat orgaan.' De leden van de Lamfalussy-comités waren alleen gebonden aan beroepsgeheimhoudingsregels wat betreft gevoelige financiële informatie.

De financiële onafhankelijkheid van de EBA, EIOPA en ESMA komt voort uit het feit dat ze uit verschillende bronnen worden gefinancierd. De twee belangrijkste inkomstenbronnen zijn de algemene begroting van de EU en contributies door de lidstaten. Daarbovenop brengen agentschappen geld in rekening voor de diensten die ze leveren. Als voorbeeld: de budgetten van de EBA voor 2013, 2012 en 2011 waren respectievelijk ongeveer 26, 21 en 13 miljoen euro, waarvan ongeveer 15, 12 en 7 miljoen euro werd gefinancierd uit contributies van de lidstaten. De bijdrage uit het EU-budget was voor deze jaren 10, 8 en 5 miljoen euro. ${ }^{22}$ De budgetten van de andere twee agentschappen vertonen een soortgelijke opbouw. Het beschikken over verschillende inkomstenbronnen maakt het voor andere instituties minder goed mogelijk om met het uitgangspunt 'wie betaalt, bepaalt' de beleidsrichting en handelingen van agentschappen te beïnvloeden. De financiering van de Lamfalussy-comités kwam in tegenstelling tot de nieuwe agentschappen van slechts één bron: de nationale autoriteiten van EU-lidstaten en observanten.

Al met al, de onafhankelijkheid van de EBA, EIOPA en ESMA houdt in dat deze agentschappen een entiteit los van de Commissie zijn en rechtspersoonlijkheid bezitten. Het impliceert het betrekken van verschillende EU-instituties, met verschillende en mogelijk conflicterende belangen, bij het benoemen en verwijderen van topambtenaren van agentschappen. Ook betekent het dat agentschappen over een autonoom budget beschikken waarbij de financiering minstens verdeeld is over twee inkomstenbronnen. Wat betreft hun politieke accountability zijn ESA's onderworpen aan verschillende rapporterings- en hoorzittingsverplichtingen ten opzichte van de representatieve EU-instituties. Daarnaast zijn de besluiten aanvechtbaar bij de rechter.

22 Statement of revenue and expenditure of the European Banking Authority (EBA) for the financial year 2013 (recast) (2013/C185/09), <http://eur-lex.europa.eu/LexUriServ/LexUriServ.do? uri=OJ:C:2013:185:0039:0044:EN:PDF> (bezocht op 19 maart 2014). 


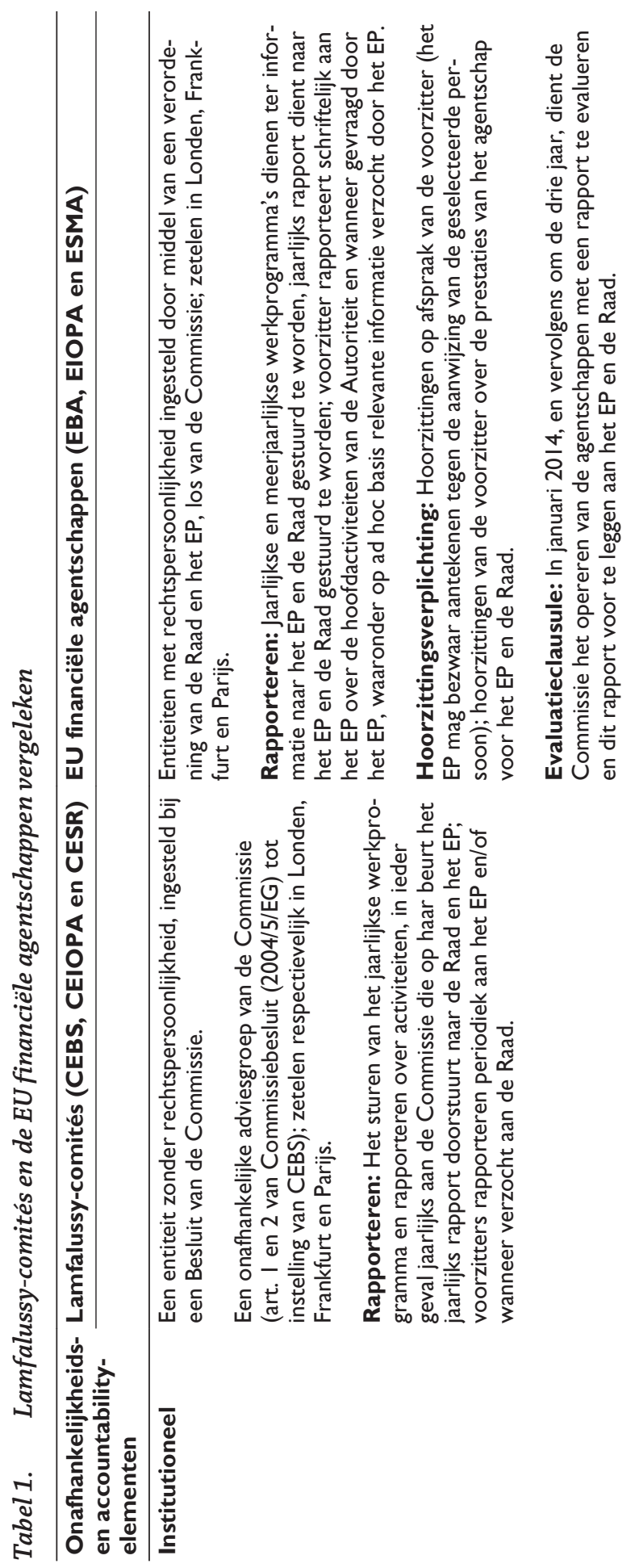




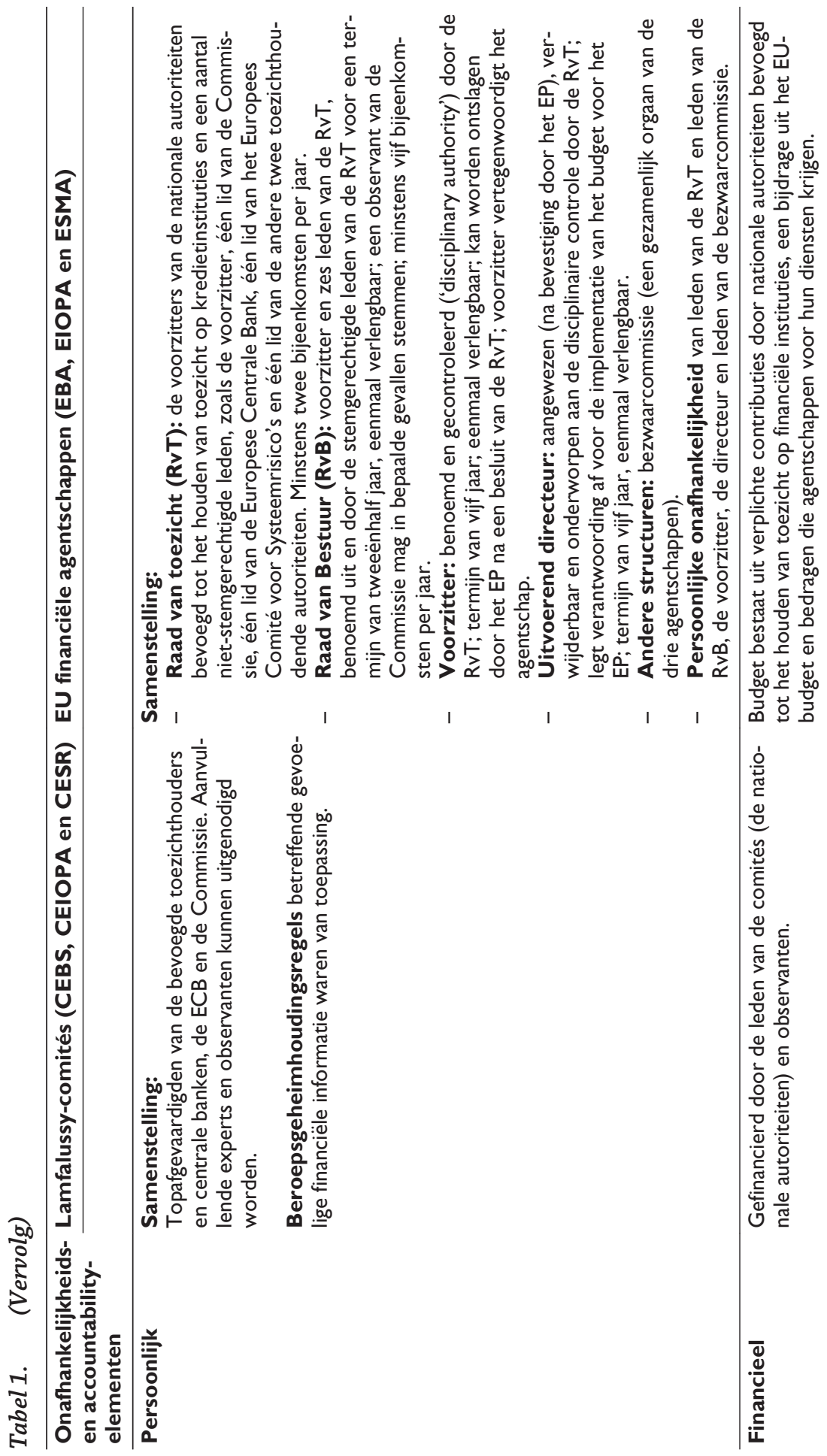




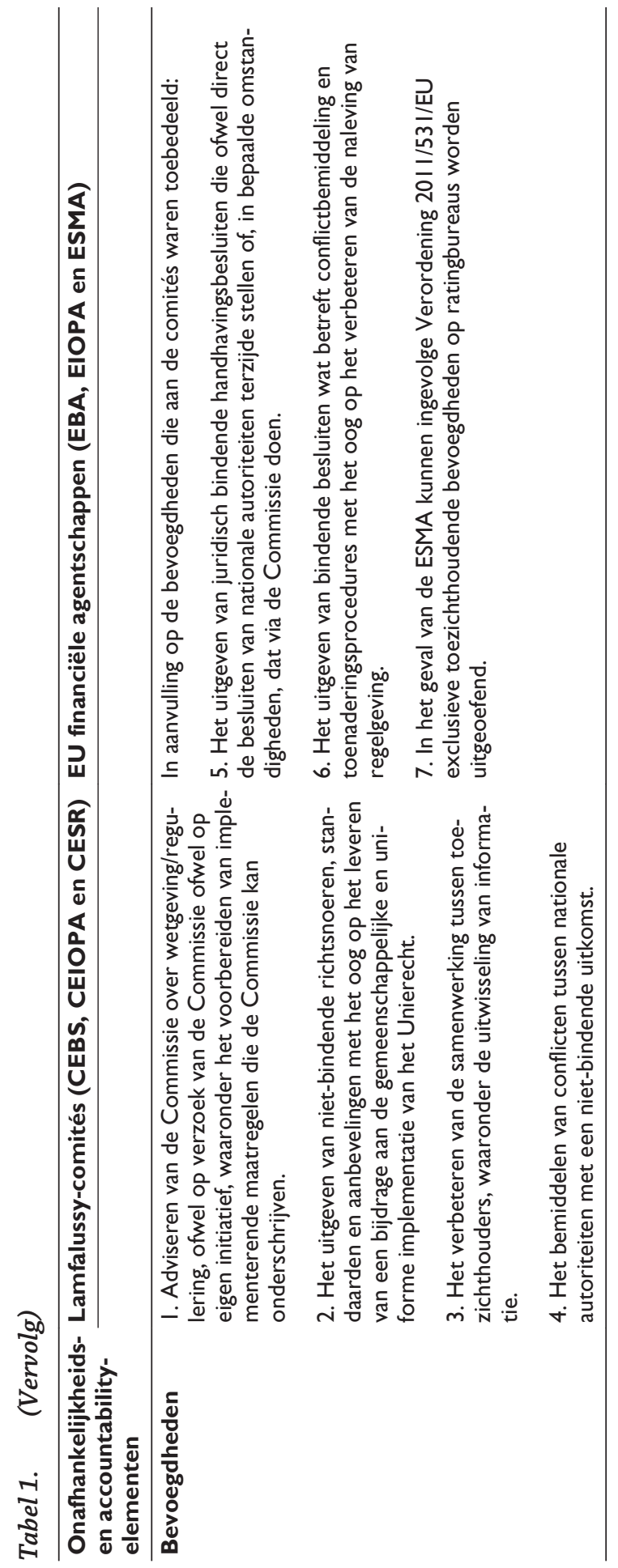




\section{De facto onafhankelijkheid en accountability}

Tot dusver heeft dit artikel de juridische ontwikkelingen omtrent de onafhankelijkheid en accountability van de nieuwe EU financiële toezichthouders bekeken. Beschreven is dat de onafhankelijkheid en accountability van de ESA's, in elk geval in vergelijking met hun voorgangers, is bevorderd. Tegelijkertijd is het belangrijk om op te merken dat juridische normen kunnen verschillen van de praktijk. Daarom is het zaak te kijken in hoeverre er mogelijke verschillen bestaan tussen de de jure verplichtingen en de de facto effecten van onafhankelijkheid en accountability van EU-agentschappen.

Wat de onafhankelijkheid van agentschappen betreft, laat Groenleer in zijn studie naar de autonomie van EU-agentschappen zien dat naast verschillen in ontwerp, de bestaande agentschappen in de praktijk ook op andere punten aanzienlijk kunnen verschillen. ${ }^{23}$ Zijn bevindingen over de ontwikkeling van de daadwerkelijke autonomie van EU-agentschappen laat grote verschillen tussen agentschappen zien, in het bijzonder met betrekking tot de vraag: 'whether they could (1) interpret their mission and role, (2) prioritise their objectives and tasks, (3) choose their clients or target audience, (4) determine their working methods, (5) draw their own conclusions or formulate their own opinions and recommendations, (6) allocate their budget and deploy their staff, and (7) enter into relations with other actors. ${ }^{24}$ Hieruit kan geconcludeerd worden dat hoewel de regelgeving de onafhankelijkheid van de ESA's heeft geprobeerd te bevorderen, de agentschappen in realiteit een grotere of kleinere mate van de facto autonomie kunnen ontwikkelen. Een empirisch onderzoek naar de kwesties genoemd door Groenleer zal uiteindelijk moeten uitwijzen hoe onafhankelijk de ESA's in de praktijk zijn geworden.

De oprichtingsaktes van de nieuwe financiële agentschappen hebben eveneens verplichtingen geïntroduceerd die bepalen aan wie en op welke wijze de ESA's verantwoording af dienen te leggen. Zo leggen de agentschappen verantwoording af voor hun prestaties door jaarlijks te rapporteren en door te verschijnen op hoorzittingen van EU vertegenwoordigende instituties (de Raad en het EP). Tegelijkertijd hangt de feitelijke verantwoording in belangrijke mate af van de frequentie en inhoud van dergelijke hoorzittingen. Recente empirische studies naar accountability van EU-agentschappen laten in dit opzicht een aantal zorgelijke ontwikkelingen zien. ${ }^{25}$ Het toezicht dat op de agentschappen wordt uitgeoefend is selectief en lijkt vooral verbonden te zijn met de politieke doelen en belangen van politici. De hoorzittingen vinden niet altijd plaats, kunnen vrij kort zijn en soms zijn er nauwelijks Europarlementariërs aanwezig. Daar komt bij dat de rapporten, hoewel ze

23 M. Groenleer, The Autonomy of European Union Agencies: A Comparative Study of Institutional Development, Delft: Eburon 2009, p. 29.

24 Ibid, p. 346.

25 Scholten 2014, voetnoot 12; M. Busuioc, The Accountability of European Agencies: Legal Provisions and Ongoing Practices, Delft: Eburon 2010; Ramboll Management-Eureval-Matrix, The Ramboll evaluation: evaluation of 26 decentralised agencies, december 2009. 
voorbereid worden door agentschappen, vaak beschrijvend in plaats van analytisch en kritisch van aard zijn, waardoor ze minder waardevol zijn in termen van accountability. Ruwweg beschrijven de bestaande rapporten de acties ondernomen door agentschappen in plaats van de resultaten die zijn bereikt, en of dit noodzakelijk, efficiënt en daadwerkelijk de intentie was (en zo ja, waarom). ${ }^{26}$ Dit is niet noodzakelijkerwijs de schuld van de agentschappen, aangezien de oprichtingsaktes vaak relatief beperkt aangeven welke informatie een jaarlijkse rapport moet bevatten. Zulke rapportagebepalingen, ook terug te vinden in de ESA-verordeningen, leggen meer de nadruk op wie het rapport moet ontvangen dan op wat de inhoud ervan dient te zijn. ${ }^{27}$ Verder worden politieke accountabilityfora geconfronteerd met meer algemene uitdagingen, zoals het grote aantal actoren van de uitvoerende macht die parlementen moeten controleren met beperkte middelen, de asymmetrie in expertise tussen toezichthouders en gecontroleerden en de ineffectiviteit van sommige sancties, zoals het inkorten van budgetten dat averechts kan werken op de effectiviteit van agentschappen.

Een aandachtspunt betreft ook de vraag waarvoor de ESA's nu precies verantwoordelijk zijn. De regulering van de financiële markten in de Unie is nog altijd een gezamenlijke onderneming van de EU en nationale autoriteiten en instituties. Het werk van de ESA's hangt in belangrijke mate af van de relevante nationale autoriteiten voor de implementatie en handhaving van EU-verordeningen en soft law. Om die reden kunnen ESA's slechts beperkt ter verantwoording worden geroepen voor de regulering van en het toezicht op financiële markten. Hoewel de nieuwe agentschappen een goede ontwikkeling zijn vanuit het perspectief van de bevordering van coördinatie en uniforme implementatie van het Unierecht op het nationale niveau, is het nadeel gelegen in het feit dat de locus van de uitvoerende macht meer diffuus is geraakt. Hoe meer instituties betrokken zijn bij de beleidsvorming en implementatiecyclus, hoe moeilijker het is om de schuld voor een beleidsfout toe te wijzen aan een specifieke instelling. Vanuit een verantwoordingsperspectief is het wat deze kwestie betreft beter om een sterke regelgever/ toezichthouder verantwoordelijk voor de gehele beleidscyclus te hebben, zoals de Amerikaanse Securities and Exchange Commission, dan een keten van zwakkere agentschappen verspreid over verschillende niveaus (EU en nationaal). Ten slotte kan het moeilijk zijn om een EU-agentschap ter verantwoording te roepen voor de 'soft law' die het produceert, als deze soft law niet wordt geïmplementeerd en gehandhaafd door nationale autoriteiten en rechters. ${ }^{28}$

26 Scholten 2011, voetnoot 5, p. 34.

27 Van de 35 EU-agentschappen hebben er maar acht statutaire rapportageverplichtingen waarbij ook analytische elementen vereist zijn, zoals het rapporteren van ex post resultaten in het licht van ex ante plannen. Bovendien hebben zes agentschappen een verplichting om bepaalde onderwerpen te benoemen in het licht van het beleidsveld van het agentschap. De resterende 24 agentschappen hebben slechts een procedurele rapportageverplichting, zoals 'the management board has to adopt the report and transmit it to the European Parliament and the Council' (Scholten 2014, voetnoot 7, p. 97).

28 Het College van Beroep voor het bedrijfsleven ( $\mathrm{CBb}$ ) legde soft law documenten vrij gemakkelijk terzijde door expliciet te refereren aan het niet-bindende karakter (CBb 31 augustus 2011, ECLI:NL:CBB:2011:BR6195, par. 4.8.3.6.). 


\section{Conclusie}

Wat kan de nationale wetgever leren van de EU-ervaring met betrekking tot het oplossen van het 'onafhankelijkheid vs. accountability' dilemma? Vanuit de jure perspectief kan de balans tussen onafhankelijkheid en accountability in de volgende manieren gevonden worden:

1 het instellen van verantwoordingsverplichtingen om direct gehoord te kunnen worden door en te rapporteren aan het parlement (institutioneel element);

2 het betrekken van verschillende partijen met mogelijk conflicterende interesses bij het benoemen van de topambtenaren van een agentschap en het opnemen van verschillende restricties die het gebruik van verwijderingsclausules limiteren (persoonlijk element);

3 het verzekeren van verschillende bronnen voor het budget van het agentschap (financieel element).

De facto onafhankelijkheid en accountability hangen aan de ene kant ervan af hoe specifiek de wetgever accountability bepalingen in relevante wetgeving formuleert en of hij zijn accountability rol kan en wil vervullen en aan de andere kant hoe het agentschap zijn missie en taken interpreteert (binnen de gegeven discretie) en of het zich aan de verkregen verplichtingen samenhangend met de gegeven budgetten kan en wil houden. 